Pelo caminho das

\section{letras e do}

patrimônio

cultural:

\author{
culturas afro
}

brasileiras nas

revistas de Duque de Caxias/RJ

\section{Amália Cristina Dias da Rocha Bezerra Universidade do Estado do Rio de Janeiro (UERJ) amaliadias@gmail.com}

\section{Eliana Santos da Silva}

Universidade do Estado do Rio de Janeiro (UERJ) mairtonesl@yahoo.com.br

\section{Resumo:}

O presente estudo se propõe analisar como a produção de conhecimento, em dois periódicos locais em Duque de Caxias: a Revista Hidra de lgoassú (1998- 2012) e a Revista Pilares da História (2002-2014), abordam a temática das culturas afro brasileiras. Assim, o objetivo é identificar como os agentes de produções estão conectadas as agências na cidade de Duque de Caxias e como articulam as produções para projetação e divulgação de ações patrimoniais na cidade.

Palavras-chave: Baixada Fluminense, Culturas afro brasileiras, História Local

\begin{abstract}
:
The present study aims to analyze how the production of knowledge in two local periodicals in Duque de Caxias: the Revista Hydra de Igoassú (1998-2012) and the Pilares da História (2002-2014) magazine address the theme of Afro-Brazilian cultures. Thus, the objective is to identify how the agents of production are connected the agencies in the city of Duque de Caxias and how they articulate the productions for the projection and disclosure of equity actions in the city.
\end{abstract}

Keywords: Baixada Fluminense, Cultures Afro Brazilian, Local History. 
Inventariar a produção de conhecimento recente sobre a temática em Duque de Caxias ${ }^{1}$ permite entender o papel de determinadas instituições na cidade, e como essas produções estão se relacionando com as leis e com o processo de valorização do patrimônio cultural das populações afro brasileiras. A proposta é identificar como os agentes de produções estão conectados as agências na cidade de Duque de Caxias, e nessa perspectiva de articulação dos agentes e das agências analisar como as produções estão sendo projetadas para divulgação e ações patrimoniais na cidade.

A produção acadêmica da região ganhou espaço em diferentes revistas que foram criadas para registrar e divulgar novas e antigas ideias sobre esse território. Dentre essas revistas, estamos considerando examinar duas que são produzidas em Duque de Caxias: Revista Hidra de Igoassu e a Revista Pilares da História, a partir do ano de criação das revistas até o ano de 2014.

Importante mencionar que esse trabalho objetivou um estudo qualitativo dos dados levantados. Entretanto, o registro e o cruzamento de dados quantitativos foram parte integrante da análise, a fim de verificar a emergência e/ou permanência das temáticas do patrimônio, das culturas afro-brasileiras da história da Baixada Fluminense e das discussões sobre educação patrimonial e relações étnico raciais. $\mathrm{Na}$ análise da produção identificada, serão examinadas como essas categorias são mobilizadas, quem são os agentes produtores e as intenções sociais da produção.

Assim, diante de uma perspectiva gramsciana, consideramos quem as escritas produzidas pelos agentes de Duque de Caxias constituem uma operação de hegemonia que busca ressignificar a relação entre os sujeitos com as representações do território. Do mesmo modo, as agências e os agentes nos permitem pensar como os intelectuais se organizam de modo coletivo, em aparelhos que buscam inserir suas demandas em formato de instituições criadas e reconhecidas pelo poder municipal. Eles disputam a configuração no Estado na sociedade local.

\footnotetext{
${ }^{1}$ Duque de Caxias é atualmente um dos municípios integrantes a Baixada Fluminense. Cabe esclarecer que a Baixada Fluminense pode ser defina como o conjunto de municípios localizados na região metropolitana da atual Cidade do Rio de Janeiro. De acordo com a classificação da FUNDREM (Fundação para o Desenvolvimento da Região Metropolitana do Rio de Janeiro), a Baixada Fluminense compõe os seguintes municípios: Duque de Caxias, Nova Iguaçu, São João de Meriti, Nilópolis, Belford Roxo, Queimados, Mesquita, Japeri. Atualmente Duque de Caxias está dividida em quarto distritos: Duque de Caxias, Campos Elísios, Imbarie e Xérem. Ver BRAZ, Antônio Augusto. De Merity a Duque de Caxias: encontro com a História da Cidade. Duque de Caxias: APPH-CLIO, 2010.p.10
} 
Pensar as culturas afro brasileiras dentro dessa perspectiva implica em considerar que o processo de construção dessa temática passa por projetos coletivos e ações individuais para o estabelecimento de um projeto de memória na região. Como esses autores produzem sobre a região, se relacionam no espaço, visto como periférico, também faz parte de um esforço de aproximação entre a educação básica e as universidades. Nesse sentido, quais seriam os envolvimentos institucionais desses agentes; como a região permitiu a construção de determinadas representações, e como a invenção, a demarcação, a disputa pelo que será reconhecido como "patrimônio" permitiram e/ou permitem que determinadas temáticas sejam forjadas nas representações sobre o território, sua história e sua população, como a temática em tela, das culturas afro-brasileiras. Dessa forma, buscamos identificar, através das disputas de memórias na região, como se construiu na história da cidade as leituras de patrimônio das culturas afro brasileiras, especialmente, a partir das produções de conhecimento existentes.

O próprio conceito de Patrimônio permite confundir o que é reconhecidamente Patrimônio Nacional, como se um termo não excluísse o outro e, dessa forma, se aplicasse uma naturalização na seleção. Os bens culturais tidos como representação da nação são os que recebem um significado simbólico e passam a pertencer a um conjunto de bens que compõe a herança cultural de uma nação. Assim, o termo patrimônio oculta algumas questões, como: Quem decide o que deve ou não ser preservado? O que realmente representa o nosso passado? (NAJJAR, 2010).

Nesse sentido, a relação entre a memória e a história é evidenciada na construção desse território através das seleções constantes que marcam a relação entre o saber e o poder. Isso pode ser visualizado através do patrimônio, entendido como forma de escrita do passado.

\section{Revista Hidra de Igoassú: faces da resistência}

A Revista Hidra de Igoassú Cadernos de textos sobre a história local e regional Baixada Fluminense foi criada em 1998. Vinculada a Associação de professores e pesquisadores de História (APPH-CLIO) a revista se apresenta como um esforço do Departamento de História da Faculdade de Duque de Caxias (FEUDUC), que em 1992 criou o Centro de Pesquisa e Documentação da História da Baixada Fluminense (CEMPEDOCH/BF). O objetivo do centro de pesquisa era identificar, catalogar e divulgar as fontes relativas a História da Baixada Fluminense e de suas 
cidades, Duque de Caxias, em particular. Nesse sentido, a partir do incentivo à produção e a publicação de pesquisas realizados pelo Departamento da FEUDUC, um órgão de divulgação se fez necessário. A Revista Hidra de Igoassú foi um produto desse período².

A revista não recebeu financiamento de Instituições públicas e/ou privada, o que gerou um limite de publicações. Duas (2) edições ocorreram em 1999 (Ano I, n. 1, abril de 1999, Ano I, n.2 julho de 1999); uma (1) edição em 2000 (Ano II, n. 3, abril/maio/junho de 2000); uma (1) edição especial em 2000 (Ano II, Edição Especial); uma (1) edição em CD em 2001; e com uma interrupção até 2012 quando aconteceu um esforço da própria equipe em realizar uma (1) nova publicação que saiu em fevereiro de 2012 (Ano I n. 1, fevereiro de 2012), ${ }^{3}$ somando um total de cinco (5) números impressos e um (1) formato CD. Esse caderno em especial, do ano de 2012, revela os interesses e a que se propõe esse trabalho na região. Demarcando as intenções dos agentes envolvidos nessa produção, e o significado desses periódicos na Baixada Fluminense.

Adotávamos o simbolismo desse nome para intitular nossa Revista. Queríamos, com essa decisão, homenagear esses homens e mulheres que lutaram contra o horror da escravidão e assinalar aos que nos leriam, que pretendíamos, tal qual a Hidra de Iguassú, travar um combate de resistência, dessa vez intelectual, provocando a região a falar de si mesma e refletir sobre suas questões. ${ }^{4}$

Assim, na apresentação da Revista de 2012 os autores, que ficaram onze anos sem realizar publicações, utilizam-se de um elemento simbólico para reforçar que essa produção ainda existia. Eles também falam da relação entre o nome da revista com o passado de resistências dos escravizados da região. No texto do editorial é destacado o estudo de Flávio dos Santos Gomes ${ }^{5}$, que aborda a resistência escrava ocorrida em Iguassú, lugar onde diversas comunidades de escravos fugitivos surgiram pouco depois de 1800 . No caso desses quilombos foram enviadas inúmeras diligências do Governo Imperial, que visavam destruir esses espaços. O Ministro da Justiça exigia medidas especiais para pôr fim os quilombos que existiam na região. Assim, os quilombos de Iguassú são comparados a "Hydra de Lerna", da mitologia grega, ou seja, quase indestrutíveis. As "cabeças" do monstro são relacionadas às comunidades de escravos fugitivos da região que atormentavam moradores e autoridades policiais.

\footnotetext{
${ }^{2}$ Texto de apresentação In Hidra de Igoassú. Edição especial Ano I no 1 fevereiro de 2012.

${ }^{3}$ Esses volumes estão disponíveis para consulta no acervo da APPH-Clio, localizado na FEUDUC.

4 Texto de apresentação In Hidra de Igoassú. Edição especial Ano I no 1 fevereiro de 2012.

${ }^{5}$ GOMES, F. S. História de quilombolas: mocambos e comunidades de senzalas no Rio de Janeiro - século XIX. Dissertação de Mestrado. Campinas: Unicamp, 1992.
} 
Dessa forma, se justificava a reedição da revista que sofreu uma longa interrupção, e que em 2012 destacava os desafios e as conquistas de um grupo de pesquisadores preocupados com a "defesa do Patrimônio, da História e da Cultura na nossa cidade e em nossa região." Esse grupo se reconhecia como os "militantes da memória" e expressavam claramente suas intenções e significados de ação levantando a bandeira da função social da História. Na parte final da apresentação da edição está uma citação do historiador Josef Fontana: “As elites dominantes não temem a História. Elas são capazes de criar aquela História que melhor thes convém. O que eles temem são os historiadores que elas não podem controlar" ${ }^{6}$.

Durante as primeiras publicações ${ }^{7}$ o corpo editorial era inicialmente composto por: Antonio Jorge Mattos (FEUDUC); Marlúcia Santos de Souza (FEUDUC); Maria do Carmo Gregório (APPH-Clio); Maria José Rodrigues. Nas edições seguintes ${ }^{8}$ não aparece o nome de Gregório. Contudo ainda são nomes dos membros da APPH-Clio e/ou professores da FEUDUC. No ano de 2012, o corpo editorial da revista contava com: Antonio Augusto Braz (Museu Vivo do São Bento ${ }^{9}$ ), Alexandre dos Santos Marques (APPH-Clio), Nielson Rosa Bezerra (Museu Vivo do São Bento, UERJ) e Tania Maria Amaro (Instituto Histórico de Duque de Caxias, UNIGRANRIO). Membros presentes tanto na sociedade civil como na sociedade política e, atualmente, são os responsáveis pelas principais atividades culturais e acadêmicas no cenário da Duque de Caxias. Eles têm apresentado a escrita da cidade como operação de hegemonia e através dessas produções de conhecimento buscam ressignificar a relação dos sujeitos com as representações locais.

$\mathrm{Na}$ apresentação da edição especial da revista que ocorre em 2001, também é possível destacar a importância da revista para a produção historiográfica na região. Essa apresentação é realizada pela professora da UFRJ, Maria Aparecida Rezende Mota. A professora menciona que desde 1999 estava desenvolvendo um Programa de Leituras sobre Teoria da História e Historiografia com os professores e pesquisadores da região. Ela comenta que a proposta era atualizar o professorado da rede pública municipal e estadual, com seminários, encontros e

\footnotetext{
${ }^{6}$ Na apresentação da edição consta a citação do historiador Josef Fontana, mas não consta referência a obra. Hydra de Igoassú. Edição especial Ano I no 1 fevereiro de 2012.

${ }^{7}$ Revista Hydra de Igoassú. Edições: Ano I, n. 1, abril de 1999; Ano I, n.2 julho de 1999.

${ }^{8}$ Revista Hydra de Igoassú, Ano II, n.3 d. especial abril/maio/junho 2000.

9 "O Museu Vivo do São Bento retrata o território como um museu, um museu de percurso que guada vestígios de presença humana em diferentes tempos, o que nos permite trilhar as pegadas deixadas por esses diversos agrupamentos sociais. " Ver: SILVA, Marisa Gonzaga e SOUZA, Marlúcia Santos "Os professores e a construção do ecomuseu no município de Duque de Caxias (RJ): um relato de experiência. “ IN PEREZ, Carmen Lucia Vidal, TAVARES, Maria Tereza Goudard, ARAUJO, Mairce da Silva. (Org.) Memória e patrimônios; experiências em formação de professores. Rio de Janeiro: EdUERJ, 2009. p.159).
} 
cursos, na busca de aperfeiçoamento e formação dos próprios quadros do Centro de Memória, Pesquisa e Documentação da História da Baixada Fluminense (CEMPEDOCH-BF). A professora chamou atenção que a edição especial é fruto das pesquisas desenvolvidas por esse grupo. Alguns resultados desse trabalho foram apresentados no XXI Simpósio Nacional da ANPUH, realizado na Universidade Federal Fluminense no ano de 2001, na sessão de comunicações coordenadas intitulada "Baixada Fluminense: História, Memória e Identidade Local".

Nesse sentido, a Revista Hidra de Igoassú é importante para avaliar a inserção da temática das culturas afro brasileiras entre os artigos. Esses profissionais que se reconhecem como "militantes da memória", também reforçaram na apresentação de 2012 o quanto estão contribuindo para pautar a história local e regional. O documento ainda destaca que: "os textos são capítulos de dissertações de associados da APPH-Clio, que levaram para o seio das Universidades, como uma estratégia de consolidação e visibilidade, os temas da cidade e da região dentro do campo da História. "10 A edição de 2012, contou coma organização dos professores Nielson Bezerra e Tânia Amaro, membros da APPH-Clio e Associação de Amigos do Instituto Histórico (Asamih). Bezerra é coordenador de pesquisas do Museu Vivo do São Bento e Tânia Amaro é diretora do Instituto Histórico de Duque de Caxias.

A edição de 2012 contou com apenas três artigos e a promessa de novas publicações. Foram os artigos de Marlúcia Santo "Entre o Rural e o Urbano-industrial: A produção de uma Região Moderna e as Disputas Políticas Locais"11. "A cultura em Duque de Caxias: os espaços de disputas de poder e a rede de sociabilidade da elite local (1930-1950) " de Alexandre Marques ${ }^{12}$; “As CEB's na Baixada Fluminense" ${ }^{13}$ de Ercília e Oliveira. Os artigos resultaram nas dissertações produzidas pelos autores.

A análise dos cinco volumes da revista, que foram publicados, com um total de quinze (15) resultou nos seguintes temas principais: disputas políticas e administrativas, com seis (6) artigos; dois (2) trabalhos sobre as relações entre memória e história; um (1) sobre espaços históricos; um (1) sobre movimento social; cinco (5) trabalhos, que abordam as contribuições e a

\footnotetext{
${ }^{10}$ Edição especial Ano I no 1 fevereiro de 2012

${ }^{11}$ SOUZA, Marlúcia. Entre o Rural e o Urbano Industrial: a produção de uma Região Moderna e as Disputas Políticas Locais. In. Revista Hidra de Igoassu. Edição Especial. Ano I no 1 fevereiro de 2012.

12 MARQUES, Alexandre. A cultura em Duque de Caxias: os espaços de disputas de poder e a rede de sociabilidade da elite local (1930-1950). In. Revista Hidra de Igoassu. Edição Especial. Ano I no 1 fevereiro de 2012.

${ }^{13}$ OLIVEIRA, Ercília. As CEB's na Baixada Fluminense. In. Revista Hidra de Igoassu. Edição Especial. Ano I no 1 fevereiro de 2012.
} 
presença da população negra na região. Sobre a temática das culturas afro brasileiras são os seguintes: "Pau para toda obra: A importância da madeira na história econômica do Recôncavo Guanabarino"14; “ 'De quando dar os anéis': a estrutura fundiária da Baixada Fluminense e suas transformações" ${ }^{15}$; “Memória de Joões: Exilio e sobrevivência na Baixada Fluminense” ${ }^{16}$; “A busca da construção do movimento negro em Duque de Caxias e São João de Meriti nos anos 80 e inicios dos anos 90: CEB's, Identidade Negra e Cidadania"17; "Rebeldia e Repressão na Baixada Fluminense- séc. XIX"18.

Desses trabalhos, apenas um tem o debate sobre a temática com Duque de Caxias como cenário. Trata-se do artigo de Ercília Coelho de Oliveira "A busca da construção do movimento negro em Duque de Caxias e São João de Meriti nos anos 80 e inicios dos anos 90: CEB's, Identidade Negra e Cidadania". O trabalho de Oliveira permite entender o processo histórico de participação do negro na esfera política e educacional dos municípios de São Joao de Meriti e Duque de Caxias e a partir da participação do negro na vida eclesiástica. Esse artigo parece ser um ensaio de sua dissertação defendida em $2005^{19}$.

Os agentes de produção apresentam como principal chave de interpretação os debates sobre as disputas políticas e as questões administrativas na região, sendo esses o maior volume de trabalhos. Interessante observar que até as pesquisas que tem como foco de análise as contribuições e as relações sociais e culturais privilegiando as populações negras, também ocorre a presença de estudos com um recorte administrativo/político, como são os trabalhos de Nielson Bezerra e de Jorge Rocha.

\footnotetext{
${ }^{14}$ BEZERRA, Nielson Rosa. Pau para toda obra: A importância da madeira na história econômica do Recôncavo Guanabarino In Revista Hidra de Igoassú Ano I V. 2 julho de 1999. p.5-11.

${ }^{15}$ ROCHA, Jorge Luis: “'De quando dar os anéis': a estrutura fundiária da Baixada Fluminense e suas transformações” In Revista Hidra de Igossú, Ano II n. 3 Abril/ maio/junho de 2000. p.19-38.

${ }^{16}$ GREGÓRIO, Maria do Carmo: “Memória de Joões: Exilio e sobrevivência na Baixada Fluminense” In Revista Hidra de Igossú Ano II edição especial 2001. p. 15-24.

${ }^{17}$ OLIVEIRA, Ercília Coelho. A busca da construção do movimento negro em Duque de Caxias e São João de Meriti nos anos 80 e inicios dos anos 90: CEB's, Identidade Negra e Cidadania. In Revista Hidra de Igoassú. Ano II n.3 2000. p .3959.

${ }^{18}$ BEZERRA, Nielson. "Rebeldia e Repressão na Baixada Fluminense - séc. XIX" In Revista Hidra de Igoassú. Ano II, Edição Especial. 2001 p 25-32.

${ }^{19}$ Oliveira. Ercília. As CEB's Duque de Caxias e São João de Meriti: Um Modelo de Igreja Voltado para o Social". Vassouras, RJ, 2005. Dissertação de Mestrado em História. USS.
} 
Apesar de entender que a produção sobre as populações afro brasileiras, para esses agentes, também está equilibrada comparando aos demais temas, ainda não é possível identificar a presença de estudos com recorte para práticas culturais. Somente o estudo de Oliveira aponta para uma abordagem das ações educacionais, mas ainda é um estudo marcado como os demais, como foco nas resistências e nas participações políticas das populações afro brasileiras na região.

Além de um espaço para apresentações de pesquisas acadêmicas, a revista também apresentou propostas de divulgação das atividades pedagógicas desenvolvidas pelos autores. Uma edição, realizada em setembro de 2001, versão em CD, foi distribuída em curso de formação continuada realizado em Duque de Caxias para os professores das redes estadual e municipal. No CD constava um título: "Hidra de Igoassú Baixada Fluminense na Sala de Aula".

A produção da Revista Igoassú sugere as conexões entre o fazer pedagógico desses agentes e suas intenções de produção acadêmica. Destaco uma parte do texto de apresentação da revista publicada via cd:

O Caderno Especial da Hidra de Igoassú é fruto das nossas investigações e do uso do investigado em nosso fazer pedagógico. É fruto do esforço de troca.

As experiências relatadas devem ser compreendidas como registros de nossas práticas e não como receitas. Elas foram feitas através de atividades para facilitar a sistematização.

O Caderno Especial titulado 'A Baixada Fluminense em Sala de Aula' é fruto também da solicitação da Associação de Professores e Pesquisadores de História APPH/CLIO e do Centro de Memória e Documentação da História da Baixada Fluminense / FEUDUC. As duas instituições apontaram a importância de favorecer o acesso dos professores a um conjunto de documentos específicos da História da Baixada Fluminense. Nesse sentido, optamos por oferecer o acesso através da edição do material que aqui apresentamos. $O$ uso ou o esquecimento do caderno é permitido, assim como, a possibilidade de operar de forma diferenciada os documentos apresentados. ${ }^{20}$

Esse trecho reforça os laços institucionais e os interesses desses agentes, que tem como foco a divulgação das pesquisas sobre a História Local. Nesse caso, o espaço acadêmico - a revista - se ressignifica para apresentar propostas pedagógicas. Essa edição oferece atividades educativas, com músicas, documentos oficiais, imagens, mapas, materiais que se propõem a

\footnotetext{
${ }^{20}$ Trecho retirado da apresentação da Revista Hidra de Igoassú, versão CD. Revista Hidra de Igoassú, Caderno especial setembro de 2001.
}

Odeere: revista do programa de pós-graduação em Relações Étnicas e Contemporaneidade - UESB. ISSN 25254715, Ano 1, número 2, volume 1, Julho - Dezembro de 2016. 
auxiliar os professores. Dentre os trabalhos, estão atividades sobre a criação do mundo, através de mitos indígenas e africanos. Atividades de história em quadrinhos com os orixás, entre outras.

A Revista Hidra de Igoassú apresentou uma proposta de romper o silêncio da história das resistências e dos movimentos sociais e sindicais na cidade. Os autores estão presentes na educação básica na região e relacionados a identificação e divulgação de locais de memória, em especial, com olhar para os agentes excluídos da historiográfica tradicional. Ana Lúcia Enne lembra que as produções desses agentes, mesmo mantendo um foco no período colonial, já apresentam temáticas ligadas à "cultura popular"21

Nesse sentido, percebe-se um movimento dos agentes, para contar uma história dos excluídos. As temáticas são ligadas às resistências, seja com abordagem sobre quilombos, mulheres e camponeses. Muitos autores dessa revista reaparecem através de suas publicações, com: livros, teses e dissertações. Eles carregam suas bandeiras temáticas nas produções de conhecimento, como caso de Ercília Oliveira, com artigos e dissertação sobre as CEB's e Identidade Negra na cidade de Duque de Caxias. Assim, esses agentes apontam quem o compromisso estava pautado nas relações entre essas atividades de pesquisa acadêmica com projeção desses saberes em práticas pedagógicas. Desse modo, desde 1999, podemos considerar que mesmo não existindo um direcionamento de valorização das chamadas "culturas afro brasileiras", como será percebido a partir de 2011 na revista Pilares da História, esses agentes já incluíam leituras de atuação tanto no campo da resistência, quanto das lideranças e das intelectualidades negras. Esses temas serão recuperados para atuação nas práticas de valorização e divulgação do patrimônio da cidade.

\section{Revista Pilares da História: Preservar e divulgar}

A Revista Pilares da História foi fundada em 2002. Trata se de uma Revista trimestral, com edição conjunta do Instituto Histórico vereador Thomé Siqueira Barreto (IHDC), da Câmara Municipal de Duque de Caxias e da Associação dos Amigos do Instituto Histórico (Asamih), a última edição ocorreu no primeiro semestre de $2016 .{ }^{22}$ A revista é composta por uma média de 5

\footnotetext{
${ }^{21}$ ENNE, Ana Lucia Silva - Lugar, meu amigo, é minha Baixada": Memória, Representações Sociais e Identidades. Rio de Janeiro, 2002. Tese de Doutorado em Antropologia Social. PPGAS/MN/UFRJ. p. 207, grifo meu).

${ }^{22}$ Revista Pilares da História. Ano XV, edição especial, maio de 2016.
}

Odeere: revista do programa de pós-graduação em Relações Étnicas e Contemporaneidade - UESB. ISSN 25254715, Ano 1, número 2, volume 1, Julho - Dezembro de 2016. 
a 8 artigos por edição, e desde a 4a edição também apresenta entre 2 a 3 textos de estudantes de graduação, na seç̧ão Visões Universitárias. Além das produções existem três seções sobre diferentes formas de documentação, são: Seção Transcrição, com a transcrição de documentos do acervo, normalmente, do IHDC; Seção Memória Viva, com entrevistas, que contemplam o acervo de História Oral do instituto; e a Seção Iconografia, que "objetiva divulgar os documentos iconográficos que integram o acervo do Instituto Histórico e das demais instituições que abrigam esse tipo de documentação" ${ }^{23}$.Em relação a Seção Transcrição, chama atenção o objetivo divulgado pela revista, que indica a preocupação dos agentes em fortalecer a identidade local através da produção de conhecimento. A Seção estaria objetivando a divulgação de documentos, e com isso, "visando a preservação das informações das fontes, através da divulgação de tão importantes referências para a história do nosso município e da região da Baixada Fluminense. Dando ciência aos pesquisadores e demais interessados sobre o conteúdo de tais documentos, firmamos a certeza de que a preservação de nossa memória histórica é importante para a construção e manutenção de uma identidade local". ${ }^{24}$

Cada número da Revista, além do editorial, apresenta uma "Mensagem do presidente da câmara municipal de Duque de Caxias", quase sempre com uma página de texto fazendo uma abertura sobre a edição ou falando sobre a importância da história e do Instituto para a preservação, tais como; “ Historiadores reafirmam a importância de Duque de Caxias”25; “A valorização da cultura e da história" ${ }^{26}$ Essas mensagens apresentam a relação entre agentes da sociedade política com atuação e interferências na e para sociedade civil. Cientes do papel da cultura e da educação para a construção do consenso, as mensagens da revista, realizadas pelos presidentes da câmara, demostram a importância da revista como um instrumento de valorização da memória e da história na região, dizendo: "uma cidade que não preserva seu passado é uma cidade sem futuro"27; e "compromisso e investimento no futuro" ${ }^{28}$. Para o do presidente da Câmara, em 2012, o vereador Dalmar Lirio Mazinho de Almeida Filho ${ }^{29}$, a maioria dos textos

\footnotetext{
${ }^{23}$ Revista Pilares da História Ano IV, n.6. abril de 2006. p.87.

${ }^{24}$ Revista Pilares da História. Ano III, n5 maio de 2005. p.97.

${ }^{25}$ Revista Pilares da História. Ano VI, n. 7, maio de 2007, p.3.

${ }^{26}$ Revista Pilares da História. Ano VII n. 8, maio de 2008, p.3.

${ }^{27}$ Revista Pilares da História. Ano II, n.5, maio de 2005, p.5

${ }^{28}$ Revista Pilares da História. Ano X, n.12, dez de 2011, p.5

${ }^{29}$ Segundo mandato de Vereador - Partido PDT Partido Democrático Trabalhista Fonte: Disponível em: <http://www.cmdc.ri.gov.br/?attachment id=3072 >Acesso em :25/10/2016.
} 
receberam títulos, desde a edição de n. 9 de 2009 até a edição especial de maio de 2012, com ênfase na relação entre cultura e educação. Na edição de 2011 ele afirma que:

As questões relativas à cultura e educação tem despertado cada vez mais interesse, mas apesar de estarem acontecendo várias ações relacionadas ao patrimônio histórico, muito ainda falta a ser implementado para que a população redescubra verdadeiramente a importância de sua própria cultura. $^{30}$

Do mesmo modo o presidente posterior, o vereador Eduardo Moreira da Silva ${ }^{31}$, também reafirma os significados desse espaço para a sociedade política, e o sentido do Estado Ampliado, nessa esfera local, ao afirmar: "incentivar ações que se recuperem o nosso patrimônio histórico cultural também são atribuições do poder público" ${ }^{32}$. Esse espaço destinado a mensagem do presidente da câmara municipal de Duque de Caxias configura essa imbricação dos projetos políticos e as disputas de memórias.

A revista também contemplou edições com destaque as comemorações sobre a cidade. A edição do Ano II, n.3 de dez/2003 foi sobre a emancipação política e administrativa de Duque de Caxias, e o presidente da Câmara do período, o vereador Laury de Souza Villar ${ }^{33}$ fez um texto sob o título: "Duque de Caxias 60 anos de História e desenvolvimento". Outra edição especial, também comemorativa, o presidente da câmara, o vereador Eduardo Moreira da Silva fala:

Comemoremos, então, nossos setenta anos, e comemoremos, também, os setenta e seis anos do Poder Legislativo e os quarenta do Instituto Histórico, pois ao comemorarmos e refletirmos, avançamos como nossa história e criamos um legado para os que virão. ${ }^{34}$

Nessa edição constam apenas três artigos: "Instituto Histórico: 40 anos de História" de Tania Amaro; "Duque de Caxias: implementação do poder legislativo" de Tania Amaro; e "Duque de Caxias: de distrito a município" de Tania Amaro e Antônio Braz. Agentes tanto da sociedade

\footnotetext{
${ }^{30}$ Revista Pilares da História. Ano X, n.12, dez 2011. p. 5

${ }^{31}$ Segundo mandato como vereador. Partido do PT e filho de Geraldo Moreira, influente político local. Disponível em: www.cmdc.ri.gov.br/?attachment id=3072/. Acesso em: 25/10/2016.

${ }^{32}$ Revista Pilares da História, Ano XII, n.13, maio de 2013. p.5.

${ }^{33}$ Vice prefeito de Duque de Caxias, no mandato de Alexandre Cardoso. (2012-2016).

${ }^{34}$ Revista Pilares da História. Ano XII, ed. Especial - out de 2013, p.3.
} 
política, no caso de Amaro com o próprio Instituto e representante da sociedade civil, como Braz, diretor do MVSB, e membro da Asamih.

Apesar dessa edição especial ter contemplado um tema comemorativo, a revista realizou poucas edições especiais, e o interessante é que são edições com foco cultural. A partir desses volumes pode se pensar um marco com publicações com recorte especifico nas práticas culturais da cidade, e nesse sentido também incluir as "culturas afro brasileiras".

A revista n. 10, agosto de 2011, contemplou as monografias sobre "manifestações culturais na cidade". Na edição especial 2012, os editores falam da importância da rede composta pela: APPH-Clio, do Instituto de Pesquisas e Análises Históricas e de Ciências Sociais da Baixada Fluminense (IPABH), Centro de Referência Patrimonial e Histórico do Município de Duque de Caxias (RPH), Centro de Pesquisa, Memória e História da Educação da Cidade de Duque de Caxias e Baixada Fluminense (CEPEMHEd) e o Fórum Cultural da Baixada Fluminense para consolidação de políticas públicas que contemplem as demandas patrimoniais defendidas por eles. Também comemoraram a inclusão da Revista na qualificação Acadêmica Qualis ${ }^{35}$, e a reedição da revista Hidra de Igoassu. Vale lembrar que os agentes do conselho editorial da Revista Hidra, em 2012 eram; Antonio Braz; Alexandre Marques, Nielson Bezerra e Tania Amaro. Os mesmo que integravam o corpo editorial da Revista Pilares, juntamente com: Carlos Sá Bezerra, José Claúdio Souza, Marlucia Souza e Rogério Torres. Assim, a edição de 2012 da Revista Pilares se apresenta como o resultado da inclusão da Asamih como Ponto de Cultura, desde 2009, com o projeto: "Tecendo as Ações no Presente. Construindo a Cidadania do Futuro", que constitui um movimento dos agentes de instituições distintas, mas com a conexão das escritas e das práticas patrimoniais.

Uma outra maneira de entender o significado desses espaços de produção e divulgação do conhecimento são as páginas finais da revista, nas quais constam os nomes dos integrantes da Associação dos Amigos do Instituto Histórico (Asamih), desde os fundadores aos contribuintes. A revista possui publicações com autores externos as instituições locais, contudo boa parte da produção é de história, membros das agências locais e contribuintes e/ou fundadores, como pode ser observado no quadro abaixo.

35 A revista está incluída na área de avaliação em História, com classificação B5. Disponível em: <https://sucupira.capes.gov.br/sucupira/public/consultas/coleta/veiculoPublicacaoQualis/listaConsultaGeralPeriodico s.jsf> Acesso :26/10/2016.

Odeere: revista do programa de pós-graduação em Relações Étnicas e Contemporaneidade - UESB. ISSN 25254715, Ano 1, número 2, volume 1, Julho - Dezembro de 2016. 
Gráfico 1: Participação das Instituições na Revista Pilares da História ( 2002-2014)

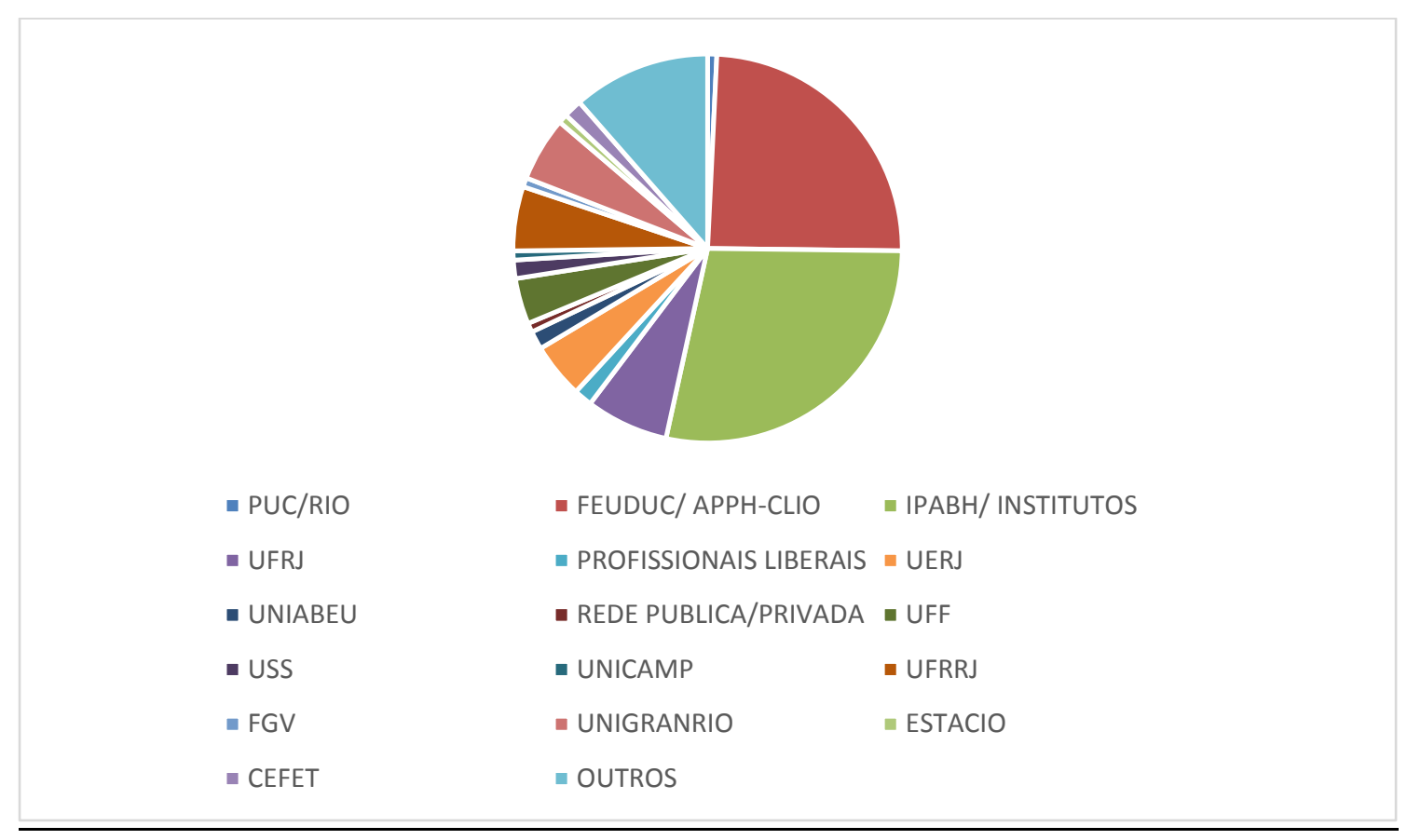

Gráfico elaborado a partir dos dados da Revista Pilares da História, 2002-2014 -18 números. Total de 131 $\operatorname{artigos}^{36}$

O levantamento na Revista identificou uma produção significativa entre os agentes oriundos da FEUDUC - graduação e pós-graduação - e os agentes do IPABH e Institutos Históricos na Baixada Fluminense. Importante mencionar que consideramos as referências de identificação da atuação profissional dos autores nos artigos. Também estamos cientes que muitos dos agentes

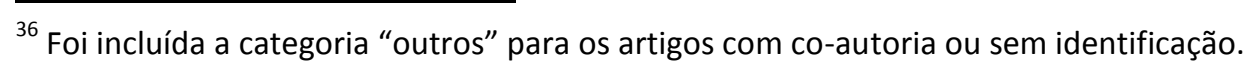


originalmente da Feuduc, atualmente estão compondo outras instituições na cidade como o CRPH, o MVSB, o CEPEMHEd. Isso demostra a complexidade da imbricação dos agentes que são professores da rede pública e/ou particular e também reaparecem nas diferentes instituições, mas que tiveram como referência inicial para produção a Associação de professores e pesquisadores (APPH-Clio), vínculo FEUDUC. Esses agentes estiveram em oposição as produções dos considerados memorialistas, em especial, os membros do IPABH. Entretanto, é interessante que eles convergem em um espaço comum, a Asamih/ IHDC. Chama atenção que os agentes na cidade valorizam e parecem entender que as disputas de memórias passam pelo poder local, no caso de Duque de Caxias, é através de um aparelho privado - IHDC - até a organização e atuação da sociedade civil, através dos pesquisadores que se reorganizam na Asamih.

A Asamih, no primeiro número da revista ${ }^{37}$, apresenta o conselho deliberativo composto por nove (9) efetivos, e nove (9) suplentes, e uma diretoria executiva, composta por: Tania Amaro, como diretora; Genises Torres, como diretor adjunto; e Nielson Bezerra, como tesoureiro. Também tinha um conselho fiscal com três (3) efetivos e três (3) suplentes. Além de um volume expressivo de sócio fundadores, apresentados em ordem alfabética, com um total de cento e sessenta e quatro (164) nomes. Esses membros estavam em duas listas seguidas, a primeira com cinquenta e um (51) e a segunda com centro e treze (113). Não foi possível identificar a distinção, mas o texto introdutório informa que a Asamih em seu estatuto, aprovado pelos sócios, previa

[...] um número ilimitado, mas composto atualmente por intelectuais e pesquisadores do maior renome na Baixada Fluminense e cidadãos comuns que manifestam interesse pela cultura e história -, o estabelecimento de intercâmbio com outras associações e entidades assemelhadas, o apoio à reprodução de documentos do Instituto Histórico, o incentivo à integração cultural com a comunidade e um programa de captação de recursos financeiros para a instalação de projetos culturais. ${ }^{38}$

Essa revista integra agentes da Revista Hidra de Igoassú e reforça o quanto na cidade de Duque de Caxias existe uma forte imbricação entre a sociedade civil e a sociedade política. Ainda na primeira edição em 2002, convém recuperar os integrantes do corpo editorial: Alexandre Marques (membro da Secretaria Municipal de Educação de Duque de Caxias, Carlos de Sá Bezerra (jornalista, fundador e diretor da Revista Rio Magazine), Odemir Capistrano Silva (jornalista);

\footnotetext{
${ }^{37}$ Revista Pilares da História. Ano I, n. 1, out, nov e dez/2002.

${ }^{38}$ Revista Pilares da História, Ano I, n.1 out/nov/dez 2002, p. 119.
} 
Ruyter Poubel (Figura proeminente na cidade de Duque de Caxias. Ex-prefeito; Empresário; Jornalista) ${ }^{39}$,_Sandra Godinho Pereira (membro da APPH-Clio); Tania Amaro de Almeida (Diretora a IHDC). Todos membros da Asamih.

A primeira apresentação editorial não foi assinada, o que permite inferir um projeto conjunto dos pesquisadores da região que integrantes tanto dos "memorialistas", como no caso de Ruyter Poubel; como dos "acadêmicos", como Alexandre Marques. No editorial intitulado “ Uma História sobre Pilotis" a primeira chamada é para o "rigor acadêmico", com ênfase que a produção de conhecimento deve ocorrer em " uma perspectiva ou um olhar não necessariamente sacralizado, mas obrigatoriamente atento ao rigor da pesquisa acadêmica" ${ }^{40}$. 0 editorial, ainda, chama atenção para o lugar social, na perspectiva de Certeau, para falar da importância que tem a operação historiográfica para a escrita sobre a história local e regional. Esse texto suscita novas questões, seria um novo momento de produção do conhecimento na região para esses agentes, a partir da criação da Associação e Amigos do Instituto Histórico?

Enne, em seu estudo sobre a rede de memória na região, apontava que tanto os agentes da sub rede 1, "memorialistas", e dos da sub rede 2, "acadêmicos", ofereciam múltiplas possibilidades de desdobramentos para análise. A rede de memória seria uma "teia de relações sociais, envolvendo diversos agentes e agências". ${ }^{41}$. Isso implicaria nas relações que os agentes vão configurando de acordo com os contextos. Desse modo, isso pode ser observado não apenas no trabalho de Enne, realizado em 2002, mas também no conselho editoral da revista em 2016, que é composto por agentes de instituições distintas na região: Alexandre Marques, Nielson Bezerra, Antônio Augusto e Marlúcia Souza seriam componentes da sub rede chamada acadêmicos. Tanto Marlúcia, Nielson e Antônio Augusto são integrantes no MVSB. Alexandre Marques é integrante do conselho de projetos culturais na prefeitura de Duque de Caxias.

Na segunda edição da revista o corpo editorial passou a contar com Rogério Torres (IPABH), também considerado um "memorialista". Foram poucas mudanças no conselho ao longo dos anos. Os membros que estão presentes desde a primeira edição, são: Alexandre Marque, Tânia Amaro; Carlos Sá Bezerra ${ }^{42}$, Rogério Torres. As alterações ocorreram no Ano VII, n. 8 (2008),

\footnotetext{
39 Poubel foi Vice-Prefeito, governou por 111 dias, nas licenças solicitadas pelo Prefeito Dr. Moacyr do Carmo. Disponível em: < http://www.cmdc.ri.gov.br/?page id=1452\#> Acesso em 16/11/2016.

${ }^{40}$ Revista Pilares da História, Ano I, n.1 out/nov/dez 2002, p. 1.

${ }^{41}$ ENNE, Ana Lucia Silva - Lugar, meu amigo, é minha Baixada": Memória, Representações Sociais e Identidades. Rio de Janeiro, 2002. Tese de Doutorado em Antropologia Social. PPGAS/MN/UFRJ.p.290.

${ }^{42}$ Ele foi jornalista e ficou no conselho até o ano de 2013, e faleceu em 2014.
} 
com a saída de Godinho e Ruyter Poubel. Somente nos números seguintes - a partir do Ano VIII, n.9 - seriam incluídos outros nomes, como: Nielson Bezerra (MVSB, UERJ); Antonio Augusto Braz (MVSB), José Claúdio Souza Alves (UFRRJ), Marlucia Santos de Souza (MVSB), incluída no Ano X, n. 12; e André Santos da Rocha (UFRRJ), incluído no Ano XII, n.13.

Desse modo, o atual conselho editorial da revista é composto por: Alexandre dos Santos Marques (SME, Asamih); Antônio Augusto Braz (MVSB, Asamih); André Santos da Rocha (UFRRJ); José Claúdio Souza Alves (UFRRJ); Nielson Rosa Bezerra (MVSB, UERJ, Asamih); Marlúcia Santos de Souza (MVSB, Asamih); Rogério Torres da Cunha (IPABH, Asamih) e Tania Maria da Silva Amaro de Almeida (IHDC, UNIGRANRIO, Asamih).

Assim, Enne trabalhando na perspectiva de rede aponta os elos presentes nessa relação. O Instituto Histórico, na pessoa da professora Tania Amaro, e o professor Rogério Torres são considerados elos intermediários nessa rede, pois transitam entre os acadêmicos es memorialistas. Do mesmo modo que o próprio IHDC é entendido por Enne, como um espaço que vai aglutinar, em certos momentos, os diferentes pontos de vista. ${ }^{43}$. Percebe-se que as imbricações entre os agentes e as agências permanecem nos dias atuais e se mantem para articular e divulgação das produções na cidade.

Os apoios à revista vêm das instituições nas quais esses agentes ocupam cargos e atuam para divulgação do conhecimento e o patrimônio da região. Eles, segundo a revista "participaram direta ou indiretamente da produção (...)" além do "empenho no difícil processo da permanente construção e reconstrução da nossa história" ${ }^{44}$. São as seguintes instituições: O CRPH; CEPEMHEd; Instituto de Pesquisas e Análises Históricas e de Ciências Sociais da Baixada Fluminense (IPAHB); o Programa Integrado de Pesquisas e Cooperação Técnica na Baixada Fluminense (PINBA/ UERJ/ Febf) e o Fórum Cultural da Baixada Fluminense. Como indica Enne, a Baixada Fluminense é composta por uma grande rede memória, composta por elos e sub elos. A Revista Pilares da História é um espaço que expressa essa realidade, pois contempla agentes dos chamados grupos "memorialistas" e do grupo do "acadêmicos". 45

Essas instituições e seus agentes são parte integrante dessa rede de memória na região, que segundo Enne, estão envolvidos com muitas relações. E nesse sentido, os agentes do IHDC

\footnotetext{
${ }^{43}$ ENNE, Ana Lucia Silva - Lugar, meu amigo, é minha Baixada": Memória, Representações Sociais e Identidades. Rio de Janeiro, 2002. Tese de Doutorado em Antropologia Social. PPGAS/MN/UFRJ.

${ }^{44}$ Revista Pilares da História - ano 15 - edição especial - maio de 2016. p.2

${ }^{45}$ Idem.
} 
foram e são importantes para estabelecer os elos. Enne fala que, inicialmente, os agentes do instituto, em especial, a professora Tania Amaro se aproximaram dos agentes da Feuduc, e foi se configurando uma maior proximidade, desde o lançamento de um dos cadernos da revista Hidra de Igoassu, no espaço do instituto até a revitalização da Associação de Amigos do Instituto, com membros das duas sub redes, como já fora apresentado. Esses laços foram se configurando desde as primeiras instituições, como a Feuduc e o IPABH, uma das instituições de referência para a sub rede dos "memorialistas", criado em 1999. Os principais nomes ligados ao IPAHB eram Gênesis Torres, Guilherme Peres, Marcus Monteiro, Ney Alberto e Rogério Torres. ${ }^{46}$

Nos dias atuais, é possível perceber que o IHDC, ainda com a direção da professora Tania Amaro, permanece com relações com os agentes de antigas instituições. Os agentes se reconfiguraram em outras instituições, como: $\mathrm{CRPH}$, CEPEMHed, bem como instituições universitárias como aa UERJ/Febf. Nas palavras de Jose Ricardo Fernandes:

A pesquisa, enquanto o componente de uma política para o Patrimônio Cultural, deverá constituir-se em elemento de informação para as diversas instituições e entidades que lidam com o Patrimônio e aos "profissionais da memória" historiadores, antropólogos, arquivistas, museólogos e educadores (...). ${ }^{47}$

São agentes e agências que entendem a produção do conhecimento e a divulgação dessas pesquisas como parte integrante dos "propósitos da Cidadania Cultural e da Educação Patrimonial” ${ }^{\prime 48}$. O editorial da revista publicada no primeiro semestre de 2016 reforça essa ideia ao afirmar:

As ações que conduzimos objetivam dar, à luz da pesquisa e da divulgação, mas subsídios aos leitores-cidadãos para que, empoderados dessas preciosas informações históricas, possam dispor de mais uma ferramenta intelectual na luta pela cidadania plena em nossa região. ${ }^{49}$

Esses profissionais também organizaram um curso de pós-graduação Lato Sensu - História Social da Baixada Fluminense - com início em 20/03/2010 e término no dia 02/04/2011. Infelizmente, as monografias realizadas não foram arquivadas e foi possível obter apenas uma lista

\footnotetext{
${ }^{46}$ Idem. p.150.

47 FERNANDES, José Ricardo Oria. Educação Patrimonial e Cidadania: uma proposta alternativa para o ensino de história. Revista Brasileira de História. São Paulo: V. 13 n. 25/26. Setembro 1992/ agosto 1993. p. 275

${ }^{48}$ Revista Pilares da História - ano XV - edição especial - maio de 2016. Editorial p.3 não tem o link?

${ }^{49}$ Revista Pilares da História - ano 15 - edição especial - maio de 2016. Editorial p.3
} 
com os alunos e títulos dos trabalhos. Contudo, a revista também divulgou parte dessas produções em três (3) artigos. ${ }^{50}$

Muitos dos artigos publicados na Seção Universitária da Revista são de alunos que realizaram trabalhos na pós-graduação Lato Sensu em História Social da FEUDUC. Alexandre Marques, Nielson Bezerra, Antonio Braz e Marlucia Souza também foram professores nesse programa e orientaram estudos que foram publicados na revista. Entre os vinte dois (22) textos, no total publicados na Seção Visões Universitária, treze (13) são de alunos da Feuduc, três (3) de alunos da UFF, quatro (4) alunos da UNIGRANRIO e dois (2) de alunos da UFRRJ.

O levantamento dos artigos demonstrou que no total de cento e trinta e um (131) publicações - sem contar os textos da seção Visões Universitária - de modo geral, é possível classificar as produções em três grandes eixos de trabalhos: treze (13) sobre História/memória; trinta e quatro (34) sobre lugares/espaços históricos; vinte e quatro (24) sobre abordagens geográficas e/ou do território. De um modo geral, o volume maior de produções é com foco em espaços e problematizações sobre o território da Baixada Fluminense. As demais publicações são sobre; ditadura militar, quatro (4); abordagem econômica, três (3); História da educação, oito (8); impacto industrial, cinco (5); personalidades, dezesseis (16); diversos, três (3).

No tocante aos trabalhos que abordam as populações afro brasileiras na Baixada Fluminense, foram identificados vinte e um (21) artigos, ou seja, depois das análises com ênfase na história do território, ou com ênfase na relação história e memória, podemos verificar um crescimento de estudos sobre as populações negras na região. Dentre as pesquisas sobre a temática, foram sete (7) trabalhos sobre sistema escravista; três (3) sobre o movimento negro; quatro (4) sobre religiosidade; três (3) sobre práticas culturais, e quatro (4) sobre liderança/ intelectualidade negra. Assim, desde o ano de 2003 podem ser identificados trabalhos com essas chaves de análise, com ênfase a partir de 2008, com uma adição especial, comemorando o centenário de Solano Trindade, que revista recebeu quatro (4) publicações sobre o assunto. E na edição especial de 2011, sobre práticas culturais na cidade, a revista recebeu seis (6) artigos envolvendo a temática.

A revista é um canal de atuação, para que diferentes visões de mundo possam compor esse campo de disputas temáticas internas na cidade. São autores que envolvidos com o território

\footnotetext{
${ }^{50}$ Revista Pilares da História: Um artigo no Ano X, n.11 maio de 2011; e dois (2) artigos na revista Ano XI, edição especial, maio de 2012.
}

Odeere: revista do programa de pós-graduação em Relações Étnicas e Contemporaneidade - UESB. ISSN 25254715, Ano 1, número 2, volume 1, Julho - Dezembro de 2016. 
desejam pautar o patrimônio da região. Pode -se dizer que os autores preocupados em debater as populações negras na cidade também tiveram esse espaço para apresentação de suas pesquisas.

Assim, entre os cento e trinta e um (131) artigos analisados da revista, consideramos que desde o ano de 2003 foi possível identificar a presença de pesquisas com seguintes os eixos: escravidão; pós abolição; diáspora africana; trajetórias de lideranças negras; as práticas educativas antirracistas e relações étnico raciais; movimento negro; e as prática culturais.

Desse modo, os agentes que escrevem sobre a temática são autores recorrentes de produção nos últimos anos, pois os eixos e os autores das teses e dissertações reaparecem na revista. O quadro abaixo apresenta como esses trabalhos estão, recentemente, destacando a temática de Joaozinho da Goméia. Do mesmo, outros temas também passam a compor as abordagens que se propõe ao reconhecimento e valorização das práticas culturais na cidade, tais como a capoeira e o samba. Essas abordagens também serão recuperadas pelos agentes da cidade nos projetos relacionados ao tema e nas práticas patrimoniais na cidade, em especial nos projetos do MVSB.

Quadro 1: Artigos sobre a população afro brasileira em Duque de Caxias (2000-2014)

\begin{tabular}{|c|c|c|}
\hline $\begin{array}{l}\text { Revista Pilares da História } \\
\text { Ano }\end{array}$ & Autor & Título \\
\hline $\begin{array}{l}\text { Ano II -n.2 } \\
\text { Maio/ } \\
2003\end{array}$ & Marlúcia dos Santos Souza & $\begin{array}{l}\text { O debate étnico e a união dos } \\
\text { homens de cor em Duque de } \\
\text { Caxias }\end{array}$ \\
\hline $\begin{array}{l}\text { Ano III- n. } 4 \text { maio/ } \\
2004\end{array}$ & $\begin{array}{l}\text { Sandra Godinho Maggessi } \\
\text { Pereira }\end{array}$ & $\begin{array}{l}\text { A trajetória do movimento negro } \\
\text { em Duque de Caxias: uma análise } \\
\text { em construção }\end{array}$ \\
\hline $\begin{array}{l}\text { Ano VIII - n9 } \\
\text { Maio/2009 }\end{array}$ & Waldemar Alvarenga Neto & O princípio da Gomeia \\
\hline $\begin{array}{l}\text { Ano VII-n8 } \\
\text { Maio/2008 }\end{array}$ & Maria do Carmo Gregório & $\begin{array}{l}\text { Solano Trindade e os dilemas da } \\
\text { identidade negra }\end{array}$ \\
\hline $\begin{array}{l}\text { Ano VII-n8 } \\
\text { Maio/2008 }\end{array}$ & Guilherme Peres & $\begin{array}{l}\text { Solano Trindade: o poeta da } \\
\text { Resistência }\end{array}$ \\
\hline $\begin{array}{l}\text { Ano VII - n8 } \\
\text { Maio/2008 }\end{array}$ & $\begin{array}{l}\text { Antônio Carlos de Oliveira } \\
\text { Magalhães }\end{array}$ & $\begin{array}{l}\text { Visões Universitárias: pré- } \\
\text { vestibular para negros e carentes } \\
\text { e biblioteca comunitária. Duas } \\
\text { histórias, um nome Solano } \\
\text { Trindade }\end{array}$ \\
\hline
\end{tabular}




\begin{tabular}{|l|l|l|}
\hline $\begin{array}{l}\text { Ano VII -n8 } \\
\text { Maio/2008 }\end{array}$ & Eldemar de Souza & Solano Trindade e eu \\
\hline $\begin{array}{l}\text { Ano X. Ed. Especial } \\
\text { Agosto/2011 }\end{array}$ & $\begin{array}{l}\text { Alexandre Marques e } \\
\text { Geraldo Filho }\end{array}$ & $\begin{array}{l}\text { Trajetória da Capoeira em Duque } \\
\text { de Caxias }\end{array}$ \\
\hline $\begin{array}{l}\text { Ano X. Ed. Especial } \\
\text { Agosto/2011 }\end{array}$ & Leonardo Fernandes Ferreira & $\begin{array}{l}\text { E a "cartolinhas" se foi: órfãos e } \\
\text { herdeiros do Samba em Duque de } \\
\text { Caxias }\end{array}$ \\
\hline $\begin{array}{l}\text { Ano X-n } 11 \\
\text { Maio/2011 }\end{array}$ & Andrea Mendes & $\begin{array}{l}\text { "Sua Majestade Tata Londirá: } \\
\text { Joãozinho da Gomeia e a } \\
\text { expansão do rito Angola no } \\
\text { Sudeste brasileiro" }\end{array}$ \\
\hline $\begin{array}{l}\text { Ano XIII-n14 } \\
\text { Maio /2014 }\end{array}$ & $\begin{array}{l}\text { Guão da Gomeia: Sacerdote do } \\
\text { candomblé em Duque de Caxias }\end{array}$ \\
\hline
\end{tabular}

Fonte: Revistas Pilares da História. Disponível: $<$ http://www.amigosinstitutohistoricodc.com.br/?page id=105

Acesso em: Dez/2015- 18 números. Total 131 artigos.

Os artigos de Marlúcia Souza e de Sandra Pereira abordam a participação do União dos Homens de Cor (UHC) em Duque de Caxias. São trabalhos que se preocupam em apresentar a atuação do movimento negro na cidade. Marlúcia é autora do livro "Escavando o passado da cidade ${ }^{51}$,e nessa obra também fala da ação dos diferentes movimentos de resistência na cidade. Já Godinho parece ensaiar sua pesquisa de mestrado, defendida em $2006^{52}$, dentro de um exercício que parece cíclico dessas produções: artigos, dissertações e livros.

Outros três trabalhos são sobre Joaozinho da Goméia, dentre eles o artigo de Peres, que é atual diretor da Asamih e possui ampla produção sobre a Baixada Fluminense, com artigos sobre a temática em outros períodos. Importante lembrar que o Instituto Histórico também possui um acervo significativo sobre o babalorixá, que contribuiu para produção local, como as fotos da Coleção Joaozinho da Goméia, divulgadas na Seção Iconografia (Ano X, n.11, maio de 2011, p.107). Outro artigo é Mendes, que apresenta parte de sua pesquisa de mestrado, que também gerou a

\footnotetext{
${ }^{51}$ SOUZA, Marlucia Santos. Escavando o Passado da Cidade - História Política da Cidade de Duque de Caxias. Duque de Caxias: APPH-Clio, 2014.

52 PEREIRA, Sandra Godinho. Vozes Afro-Caxienses: Ecos Políticos-culturais dos Movimentos de Resistência Negra em Duque de Caxias (1949-1968). Dissertação de Mestrado. Vassouras: USS. 2006.
} 
publicação do livro em $2014^{53}$, por ocasião das comemorações do centenário de Joaozinho da Goméia.

A exemplo de outros momentos na região, as escritas parecem compor as atividades comemorativas, especialmente, no contexto de comemorações centenárias. Como no caso dos artigos de Gregório, Peres, Magalhaes, Souza, produções que compõem um número da Revista Pilares, em 2008. Esses artigos parecem que contemplaram parte das comemorações do centenário de nascimento do poeta. Um dos atores diz que "tal iniciativa tem razão ser, pois foi neste município que Solano viveu vários anos das décadas de 40/50. "54.

Assim, além da edição da revista outras atividades aconteceram, dentre elas a visita de integrantes do Conselho Municipal em Defesa do Direito do Negro e Promoção da Igualdade Racial e Étnica (Codedine) a Estância Turística em Embu das Artes em São Paulo. Segundo Souza, a visita contemplava outros interesses, tais como:

Os caxienses não foram lá apenas marcar presença, como representantes de um conselho de pluralidade étnica. Se o fizessem, estariam cumprindo seu papel, mas foram dispostos a negociar a extensão do evento a Caxias, através de diversas atividades realizadas na cidade, ao longo do primeiro semestre deste ano. ${ }^{55}$

O movimento que articula escrita, eventos e a participação política é expresso no texto de Souza que contém uma página. O texto "Solano Trindade e eu" apresenta as relações que o autor reconhece ter com o poeta. Souza é jornalista e escritor, e diz que o primeiro contato com Solano ocorreu em São Paulo. Ele apresenta um pouco da vida do poeta e de seu cotidiano apontando dados como: "em sua casa, entre residentes, agregados, vizinhos e turistas de várias procedências, passei fins de semana memoráveis (...). ${ }^{56} \mathrm{O}$ texto de Souza é um dos que compõe, de certa forma, uma homenagem a Solano Trindade. Além de noticiar alguns dados que envolveram as etapas de comemorativas, ele também apresenta um pouco de sua vida e a vida do poeta.

Os outros artigos contribuem, no sentido de recuperar um pouco da trajetória de Solano Trindade. Este é o caso do texto de Peres, que além de contar um pouco da vida do poeta, também mostra memórias e atuações culturais realizadas na cidade através de dados da

\footnotetext{
${ }^{53}$ MENDES, Andrea Luciene Rodrigues. Vestidos de realeza: fios e nós centro-africanos no candomblé de Joãozinho da Gomeia. Série Recôncavo da Guanabara. V1. Duque de Caxias, RJ: APPH-CLIO, 2014.

${ }^{54}$ SOUZA, Eldemar de. Solano Trindade e eu. In. Revista Pilares da História. Ano VII, n.8, maio de 2008.p. 25.

55 Idem, p.25.

${ }^{56}$ Idem, p.25
}

Odeere: revista do programa de pós-graduação em Relações Étnicas e Contemporaneidade - UESB. ISSN 25254715, Ano 1, número 2, volume 1, Julho - Dezembro de 2016. 
imprensa, especialmente, no jornal "Grupo". Além de terminar o artigo com o tópico "resgate", lembrando que:

No dia 14 de julho de 2008, José Francisco Solano Trindade faria 100 anos de existência. É hora de Duque de Caxias resgatar sua memória, transformando esse monstro sagrado da poesia em nome de rua, praça ou escola, em agradecimento ao seu trabalho. e aos poemas que ele semeou em homenagem à cidade ${ }^{57}$

Esse registro aponta as diferentes formas que os agentes acionam temas do passado para pensar e atuar na cidade, sendo recorrentes em eventos comemorativos. $\mathrm{O}$ último artigo que compõe a homenagem é da autora Gregório, que reaparece no cenário, com parte de sua dissertação, como consta no próprio artigo. Ela informa que "este texto é um fragmento da minha dissertação de mestrado defendida em 2005 no PPGHIS/IFCS-UFRJ" ${ }^{58}$

Além dos artigos na revista também foram divulgadas, através das seções, um pouco do acervo sobre os temas abordados. Na seção Transcrição (Ano VII, n.8, maio de 2008, p.72-73), são apresentados os poemas de Solano Trindade, que integram um livro "Tem Gente com Fome e Outros Poemas; Antologia Poética, RG DG10", 1988. Na seção Iconografia (Ano IV, n.6, abril de 2006, p. 95) são apresentadas fotos de Joaozinho da Gomeia e de Pai Waldomiro Baiano, lideranças religiosas de terreiros de Candomblé em Duque de Caxias. E a seção Memória Viva (Ano VI, n.7, maio 2007, pp. 77-82) apresentou a entrevista realizada por Alexandre Marques com o senhor José Barbosa da Silva, Mestre de Capoeira. Essas seções apresentam em suas justificativas a preocupação da divulgação das fontes, mas do que apenas preservar. Como pode ser evidenciado nas aberturas da Seção Transcrição:

A preservação não é um fim em si mesma. Só preservamos para que as informações contidas nos bens culturais possam favorecer o homem no resgate de sua identidade e de sua história, permitindo, assim, o exercício pleno da sua cidadania. ${ }^{59}$

\footnotetext{
57 PERES, Guilherme. Solano Trindade: o poeta da Resistência. In. Revista Pilares da História. Ano VII, n.8, maio de 2008. p.24.

${ }^{58}$ GREGÓRIO, Maria do Carmo. Solano Trindade e os dilemas da identidade negra. IN. Revista Pilares da História. Ano VII, n. 8, maio de 2008. p. 7.

${ }^{59}$ Revista Pilares da História Ano X, n.11, maio de 2011, p.98.
} 
Nos últimos cinco anos a Revista tem apresentado mais artigos e documentação associada a "cultura popular", na perspectiva de não hierarquizar saberes. A edição Especial (Ano X, Edição Especial, agosto de 2011) foi resultado de um concurso de monografias aos pesquisadores da cidade para que apresentassem "o tema Cultura em suas mais diversas manifestações" ${ }^{60}$. O editorial reforça que a Asamih como Ponto de Cultura vinculado à Secretaria de Cultura do Estado do Rio de Janeiro com o projeto "Tecendo as ações no presente. Construindo a cidadania do futuro", afirma a responsabilidade de expor através da revista "a oportunidade de nossa gente falar de si, ler a si mesma e construir, pela interpretação mais segura de sua realidade, instrumentos de ação cidadã. " ${ }^{61}$.

Essa edição com artigos sobre: Capoeira, Samba Escravidão, demostra como o tema "culturas afro brasileiras" está sendo forjado na cidade nos últimos 5 anos e que a escrita é um instrumento legitimador para o reconhecimento desses patrimônios. O texto Mensagem do Presidente da Associação e Amigos do Instituto Histórico escrito por Paulo Christiano Mainhard ${ }^{62}$ diz que a cultura "ao contrário do que pensam alguns, é todo o conjunto do fazer, pensar e sentir. Por isso, além de ter um caráter erudito, tem também importante expressão social” ${ }^{63}$. Ele reforça que os integrantes da Asamih se sentem orgulhosos com a publicação dessa revista, pois a revista fez " uma radiografia da cultura caxiense e revela, trazendo à cena, estudiosos, pesquisadores e analistas, os quais vêm brilhantemente se debruçando sobre esse importante patrimônio da sociedade e da nossa cidade. "64

São diferentes temas abordados nessa edição, tais como: Folia de Reis; Demografia escrava no Recôncavo da Guanabara; Fazenda São Bento; Samba; Militante Comunista; Capoeira. Nessa edição sobre "cultura", os textos sobre culturas afro brasileiras em Duque de Caxias são os textos de Leonardo Ferreira: “E as 'cartolinhas' se foi: órfãos e herdeiros do Samba em Duque de Caxias"; e o texto de Alexandre dos Santos Marques e Geraldo da Costa Filho: "Trajetória da capoeira em Duque de Caxias".

Sobre o texto da capoeira o autor Marques é recorrente no debate sobre a temática na cidade, em especial, por que foi o coordenador nacional da ação Griô Nacional, na cidade de

\footnotetext{
${ }^{60}$ Revista Pilares da História. Ano X, Edição Especial, agosto de 2011, p.1.

${ }^{61}$ Revista Pilares da História. Ano X, Edição Especial, agosto de 2011, p.1.

62 Paulo Christiano Mainhard era diretor da Faculdade de Educação da Baixada Fluminense. (FEBF). A UERJ em Duque de Caxias. Desde o Ano X, n. 10 foi o presidente da Asamih.

${ }^{63}$ Revista Pilares da História. Ano X, Edição Especial, agosto de 2011, p.5.

${ }^{64}$ Revista Pilares da História. Ano X, Edição Especial, agosto de 2011, p.5.
} 
Duque de Caxias, e Filho além de especialista em História Social, é mestre de capoeira. Já o texto de Ferreira é uma abordagem nova entre os artigos apresentados na revista, e o autor não é citado entre a rede de memória recorrente na cidade. Ele não possui currículo na plataforma Lattes, o que inviabilizou recuperar sua trajetória profissional e acadêmica.

Assim, outros olhares sobre as vivências das populações afro brasileiras na cidade, no sentido de valorização, se configuram. Tanto que a Lei que dispõe sobre o Tombamento de Bens Materiais e Imateriais no Município de Duque de Caxias é de 2009. (Lei 2300 de 16 de dezembro de 2009). Esse documento consta na Seção Transcrição (Ano XII, n.13, maio 2013). O tema sobre o samba também passa a compor as páginas da revista, como por exemplo o depoimento na seção Memória Viva do "sambista e militante cultural Bira da Vila" (Ano X, n.11, maio 2011 p. 101). Ele lançou o cd "O canto da Baixada" com compositores da Baixada Fluminense. Na edição de 2014, também na seção Memória Viva, consta o depoimento do vice-secretário de Cultura, André Oliveira, sobre os desfiles dos Blocos carnavalescos de Duque de Caxias.

Tanto as fontes produzidas ou utilizadas pelos pesquisadores foram divulgadas na revista, com destaque para as vozes e as ações de determinados agentes, que foram escolhidas por esses pesquisadores para contar a história de Duque de Caxias. Isso tem visibilidade desde o projeto sobre a história dos bairros realizado pelo professor Antônio Augusto na Feuduc, em 1995. Ele diz que o acervo era "focado na vida dos protagonistas mais simples da História da Baixada Fluminense. Homens e mulheres migrantes, recém-chegados à região, que enfrentando enormes sacrifícios construíram suas vidas e de suas famílias. "65 Nesse sentido, percebe-se uma recorrência de autores nas produções que demonstram não apenas a temática posta em pauta, mas também os usos da escrita para uma reflexão sobre os significados desse espaço para esses agentes.

Através da recorrência dos escritores nessas produções é possível perceber como eles são acionados ou se apresentam para determinadas edições da revista, de acordo com as circunstâncias conjunturais dos debates na cidade. Verifica-se também que a apesar da recorrência dos agentes, eles também realizam convites a outros pesquisadores que não estão, necessariamente, presentes na cidade ou produzindo na cidade, mas que em certa medida, falam sobre a mesma. Seriam os estudos de outros pesquisadores, como no caso de Andrea Mendes.

\footnotetext{
${ }^{65}$ Revista Pilares da História. Ano VIII, n. 9, maio de 2009, p.100.
} 
Esses estudos, que falam sobre a Baixada Fluminense, no sentido de fortalecer e divulgar a história e as memórias desejadas, são acionados pelos agentes na região. Como já apontando por Enne $^{66}$, os agentes que produziam na Baixada Fluminense estavam se relacionando com os agentes que realizavam produções da Baixada Fluminense.

Assim, era uma prática recorrente dos agentes um diálogo com os autores que ela configura como elos fantasmagóricos. No caso da sub rede dos "memorialistas" eram mencionados ou referenciados certos nomes que não estavam presentes fisicamente, mas que suas obras eram referências, como: José Lustosa, Waldick Pereira, Jose Matoso Maia Forte. Para os "acadêmicos", os elos fantasmagóricos eram: Mário Grynszpan, Flávio Gomes, José Claúdio. ${ }^{67}$ Isso reforça o quanto os agentes dessa rede de memória consideram as produções do conhecimento com parte integrante de seus projetos de memória e história, e desse modo estão em constante diálogo com as produções e pesquisas sobre a região.

\section{Considerações Finais}

As produções sobre a temática na cidade de Duque de Caxias permitiram apontar algumas instituições que favorecem a participação dos agentes. Eles se articulam, produzem, publicam e dialogam com outros pesquisadores, no sentido de promover a valorização das culturas afro brasileiras e buscando na rede de memória espaço que convergem com seus projetos de memória sobre a região.

Nota-se que um conjunto de professores e pesquisadores buscam consolidar em Duque de Caxias um projeto de memória. A proposta é evidenciar as experiências e as contribuições históricas de diferentes segmentos da população, não apenas das elites. Nesse sentido, as revistas parecem ser canais na cidade de Duque de Caxias para a relação entre pesquisas e práticas patrimoniais. Assim, na busca de trabalhos relacionados as "culturas afro brasileiras", foi possível identificar obras que desde os anos 2000 tem as populações afro brasileiras como foco de análise para participação e atuação histórica no território. Nessa perspectiva, com as recentes medidas públicas relacionadas ao patrimônio imaterial, também foi possível identificar um foco, ou um

\footnotetext{
${ }^{66}$ ENNE, Ana Lucia Silva - Lugar, meu amigo, é minha Baixada": Memória, Representações Sociais e Identidades. Rio de Janeiro, 2002. Tese de Doutorado em Antropologia Social. PPGAS/MN/UFRJ.

67 Idem. p.15.
}

Odeere: revista do programa de pós-graduação em Relações Étnicas e Contemporaneidade - UESB. ISSN 25254715, Ano 1, número 2, volume 1, Julho - Dezembro de 2016. 
crescimento de produções, a partir dos anos 2011 para uma leitura das práticas culturais e as vivências religiosas, com ênfase de valorização e divulgação.

Com uma significativa presença de trabalhos que foram resultados de pesquisas sobre o território percebe-se que as revistas são uma ferramenta adequada para a divulgação das temáticas em questão. Assim, as teses e dissertações passam a circular em outro formato artigos- o que permite o acesso e divulgação dessas escritas, em especial como material para debates nos cursos de formação na cidade. Nesse sentido, tanto a Revista Hidra de Igoassú, quanto a Revista Pilares da História, em suas apresentações e editoriais, revelam o desejo de substanciarem a educação escolar e patrimonial sobre a cidade de Duque de Caxias.

\section{Referências}

ACANDA, Jorge Luís. Hegemonia e sociedade civil. In ACANDA, Jorge Luís Sociedade Civil e Hegemonia. Rio de Janeiro: Editora UFRJ, 2006.

ALMEIDA, Tânia Maria da Silva Amaro. Olhares sobre uma cidade refletida: Memória e Representações de Santos Lemos sobre Duque de Caxias (1950-1980). Duque de Caxias: ASAMIH, 2014.

ALVES, José Cláudio de Souza. Dos barões ao extermínio: uma história da violência na Baixada Fluminense. Duque de Caxias: APPH-CLIO, 2004.

BEZERRA, Nielson Rosa. Pau para toda obra: A importância da madeira na história econômica do Recôncavo Guanabarino In Revista Hidra de Igoassú Ano I V. 2 julho de 1999. p.5-11 . "Rebeldia e Repressão na Baixada Fluminense - séc. XIX" In Revista Hidra de Igoassú. Ano II, Edição Especial. 2001 p 25-32. . Tensões e interações das relações sociais em torno do regime escravista na freguesia de Santo Antônio da Jacutinga In Revista Pilares. Ano II n 2 maios de 2003. p 7 -18 As chaves da Liberdade: estratégias de resistência escrava na ferrovia In Revista Pilares. Ano III no 4 aio de 2004 p 26-45

As confluências da escravidão no Recôncavo da Guanabara: Iguaçu e Estrela (1833-1888). Dissertação de Mestrado. Programa de Mestrado em História. Universidade Severino Sombra, Vassouras, 2004.

- As chaves da liberdade: confluências da escravidão no Recôncavo do Rio de Janeiro, 1833-1888. Niterói: EdUFF, 2008.

Mosaicos da Escravidão: identidades africanas e conexões atlânticas no Recôncavo do Rio de Janeiro, 1780-1840. Tese de Doutorado. Programa de Pós-Graduação em História. Universidade Federal Fluminense, Niterói, 2010.

. Escravidão, Farinha e Comércio no Recôncavo do Rio de Janeiro, século XIX. Duque de Caxias, RJ: APPH-CLIO, 2011. 
"Marinheiros e barqueiros africanos no Recôncavo da Guanabara-século XIX" In Revista Recôncavo V. 1 n. 1 agosto - dez de 2011. p. 4-24.

- A Cor da Baixada: Escravidão, Liberdade e Pós Abolição no Recôncavo da Guanabara. Duque de Caxias, RJ: APPH-CLIO, 2012.

. A historiografia tradicional e a invisibilidade da escravidão na Baixada Fluminense.

Duque de Caxias, RJ, 2014 - mimeo.

BRAZ, Antônio Augusto. De Merity a Duque de Caxias: encontro com a História da Cidade. Duque de Caxias: APPH-CLIO, 2010.

BUTTIGIEG, Joseph A. Educação e Hegemonia. In COUTINHO, Carlos Nelson; TEIXEIRA, Andrea. Ler Gramsci, entender a realidade. Rio de Janeiro: Civilização Brasileira. 2003.

CERTEAU, Michel de. A Escrita da História. Rio de Janeiro: Forense Universitária, 1982.

ENNE, Ana Lucia Silva - Lugar, meu amigo, é minha Baixada": Memória, Representações Sociais e Identidades. Rio de Janeiro, 2002. Tese de Doutorado em Antropologia Social. PPGAS/MN/UFRJ.

FERREIRA, Leonardo Fernandes. E a "cartolinhas" se foi: órfãos e herdeiros do Samba em Duque de Caxias. In. Revista Pilares da História. Ano X. ed. Especial. Agosto 2011. p.48-67.

FONTANA, Josep. A história dos homens. Bauru, SP: EDUSC, 2004.

FORTE, José Matoso Maia. Memória da Fundação de Iguassú. Rio de Janeiro: Typ. Jornal do Comércio, 1933. 2008.

GOMES, Flavio. S. História de quilombolas: mocambos e comunidades de senzalas no Rio de Janeiro - século XIX. Dissertação de Mestrado. Campinas: Unicamp, 1992.

GONÇALVES, José Reginaldo Santos Gonçalves: O Patrimônio como categoria de pensamento. In CHAGAS, Mário e ABREU, Regina. Memória e Patrimônio. Rio de Janeiro: DP\&A editora, UNIRIO, Faperj, 2003.

GREGÓRIO, Maria do Carmo: “Memória de Joões: Exilio e sobrevivência na Baixada Fluminense" In Revista Hidra de Igossú Ano II edição especial 2001. p. 15-24

GREGÓRIO, Maria do Carmo. Solano Trindade: Raça e classe, poesia e teatro na trajetória de um afro brasileiro. (1930-1960). Dissertação de Mestrado. Programa de Pós-Graduação em História. Universidade Federal do Rio de Janeiro, Rio de Janeiro, 2005.

. Solano Trindade e os dilemas da identidade negra. IN. Revista

Pilares da História. Ano VII, n. 8, maio de 2008. p. 7-19.

CEAP, 2009.

. "Solano Trindade: "O Poeta das Artes do Povo". Rio de Janeiro:

GRYNZPAN, Mário. Mobilização Camponesa e competição Política no Estado do Rio de Janeiro (1950-1964). Rio de Janeiro,1987. Dissertação de Mestrado, Museu Nacional.

Odeere: revista do programa de pós-graduação em Relações Étnicas e Contemporaneidade - UESB. ISSN 25254715, Ano 1, número 2, volume 1, Julho - Dezembro de 2016. 
LACERDA, Stélio, TORRES, Rogério. Pelos Caminhos que a História Deixou: Passeios culturais aos principais sítios e monumentos históricos de Duque de Caxias e municípios circunvizinhos (19921994). Rio de Janeiro: Renascer, 2004.

LACERDA, Stélio. A fábrica de tecidos do "Corte Oito". Duque de Caxias, RJ: Portal Literário, 2007.

LACERDA, Stélio. Antes que o tempo apague. Rio de Janeiro, RJ: Portal Literário Editora, 2007.

LACERDA, Stélio. Caxias de ontem: um pouco de memória. Rio de Janeiro, RJ: Fábrica de Livros SENAI/RJ, 2003.

LEITE, Barboza. O chão dos caminhos. Rio de Janeiro: Editora Cátedra, 1979.

LE GOFF, Jacques. História e Memória. Campinas: Editora da Unicamp, 2003.

LOPES, Juliana, A ação griô: uma proposta política nacional. In CALABRE, Lia e BARBOSA, Frederico (Org.) Pontos de Cultura: olhares sobre o programa cultura viva. Brasília: Ipea, 2011. p. 139-154.

LUSTOSA, José. Cidade de Duque de Caxias: desenvolvimento histórico do município: dados gerais. Rio de Janeiro: Sev. Gráfica do IBGE, 1958.

MAGALHAES. Antônio Carlos de Oliveira. Pré-vestibular para negros e carentes e biblioteca comunitária. Duas histórias, um nome Solano Trindade. In. Revista Pilares da História. Ano VII- n. 8, maio de 2008. p.58-62

MARQUES, Alexandre dos Santos. Militantes da Cultura em área periférica Duque de Caxias (19501980). Dissertação de Mestrado em História. Vassouras: USS. 2005.

MARQUES, Alexandre dos Santos. Centro de Memória: caminhos e descaminhos na produção da história da Baixada Fluminense In Revista Pilares da História. Ano I no 01. Ed. Out/nov/dez 2002. p.79-94.

MARQUES, Alexandre, FILHO, Geraldo. Trajetória da Capoeira em Duque de Caxias. In. Revista Pilares da História. Ano X. Ed. Especial, agosto de 2011. p.79-90.

MATTOS, Marcelo Badaró. Cultura. In. MATTOS, Marcelo Badaró. E.P. Thompson e a tradição de crítica ativa do materialismo histórico. Rio de Janeiro: Editora UFRJ, 2012, p.117-205.

As bases teóricas do revisionismo: o culturalismo e a historiografia brasileira contemporâneas. In MELO, Demian Bezerra (Org.). A miséria da historiografia: uma crítica ao revisionismo contemporâneo. Rio de Janeiro: Consequência, 2014, p. 67-98.

MENDES, Andrea Luciene Rodrigues. Vestidos de realeza: fios e nós centro-africanos no candomblé de Joãozinho da Gomeia. Série Recôncavo da Guanabara. V1. Duque de Caxias, RJ: APPH-CLIO, 2014. 
MENDES, Andrea "O rei do candomblé nas páginas da revista: Joãozinho da Goméia em o cruzeiro (1967) "In Revista Recôncavo V. 4 n. 6, Jan - junho de 2014. p.58-78.

MENDES, Andrea. Sua Majestade Tata Londirá: Joãozinho da Gomeia e a expansão do rito Angola no Sudeste brasileiro. In. Revista Pilares da História. Ano X, n.11, maio de 2011. p.11-19.

MENDONÇA, Sonia Regina de. O Estado Ampliado como ferramenta metodológica In Revista Marx e o Marxismo. V.2, n2, jan/jul 2014. p.27-43.

MOTA, Rubens da. Por entre Pântanos e Montanhas: um olhar demografia escrava no Recôncavo da Guanabara. In. Revista Pilares da História. Ano X, Edição Especial, agosto de 2011, p.24-36.

NAJJAR, Jorge. Educação Patrimonial e Identidade: algumas questões em debate. " In: CARNEIRO, Valdeck (et al.) (org.) Movimentos instituintes em educação: políticas e práticas. Niterói: Intertexto, 2010.

NETO, Waldemar Alvarenga. O princípio da Gomeia. In. Revista Pilares da História. Ano VIII, n. 9, maio de 2009. p.55-62.

NORA, Pierre. Entre Memória e História: a problemática dos lugares. In: Projeto História, n. 10, dezembro/1993. São Paulo: PUC/SP.

OLIVEIRA, Anderson José Machado de. "As Irmandades dos homens de cor na América Portuguesa: à guisa de um balanço historiográfico" In Revista Recôncavo V. 3 n.5, Julho - dez de 2013. p. 1-14.

OLIVEIRA, Ercília Coelho. A busca da construção do movimento negro em Duque de Caxias e São João de Meriti nos anos 80 e inicios dos anos 90: CEB's, Identidade Negra e Cidadania. In Revista Hidra de Igoassú. Ano II n.3 2000. p .39-59.

OLIVEIRA, Ercília Coelho de. Movimento Negro -celebrando 25 anos na Baixada Fluminense In Revista Pilares. Ano IX no 10 maio de 2010.

. As CEB's Duque de Caxias e São João de Meriti: Um Modelo de Igreja Voltado para o Social". Vassouras, RJ, 2005. Dissertação de Mestrado em História. USS.

. Movimento Negro - celebrando 25 anos na Baixada Fluminense In Revista Pilares. Ano IX n. 10 maio de 2010. p.52-61.

POLLAK, Michael. Memória, esquecimento e silêncio. Estudos Históricos. Rio de Janeiro, vol.2, no 3, 1989, p. 3-15.

200-215. . Memória e Identidade Social. Estudos Históricos. Rio de Janeiro, vol. 5, no 10, 1992, p

PEREIRA, Sandra Godinho Maggessi. A trajetória do movimento negro em Duque de Caxias: uma análise em construção In Revista Pilares. Ano III no 4 aio de 2004 p 72-81

PEREIRA. Sandra Godinho Maggessi. A trajetória do Movimento Negro em Duque de Caxias: Uma análise em construção In: Revista Pilares da História. Ano III - n. 04 maios de 2004. p.72-82. 
- Vozes Afro-Caxienses: Ecos Políticos-culturais dos Movimentos de Resistência Negra em Duque de Caxias (1949-1968). Dissertação de Mestrado. Vassouras: USS. 2006.

PERES, Guilherme. Mercado Negro - Escravidão e Liberdade In Revista Pilares. Ano VI no 7 maio de 2007 p.26-31.

PERES, Guilherme. Mercado Negro, Escravidão e Liberdade. In. Revista Pilares da História. Ano VI, n.7, maio de 2007. p.26-31

PERES, Guilherme. Solano Trindade: o poeta da Resistência. In. Revista Pilares da História. Ano VII, n.8, maio de 2008. p.20-24.

PERES, Guilherme. João Cândido: Herói dos direitos humanos. In. Revista Pilares da História. Ano VIII, n.9, maio de 2009. p.63-68.

PERES, Guilherme. Cemitério de escravos em Nilópolis In. Revista Pilares da História. Ano XII, n.13, maio de 2013.p.52-55.

PERES, Guilherme. João da Gomeia: Sacerdote do candomblé em Duque de Caxias. In. Revista Pilares da História. Ano XIII, n.14, maio de 2014.p.75-78. . Baixada Fluminense: os caminhos do ouro. Rio de Janeiro: Consócio de

Edições, 1996.

PEREIRA, Waldick. Cana, café e laranja: história econômica de Nova Iguaçu. Rio de Janeiro: FGV, 1977.

REVEL. J. (org.) Jogos de escala: a experiência da microanálise. Rio de Janeiro: FGV, 1998.

ROCHA, Jorge Luis: “'De quando dar os anéis': a estrutura fundiária da Baixada Fluminense e suas transformações" In Revista Hidra de Igossú, Ano II n. 3 Abril/ maio/junho de 2000. p19-38.

SILVA, Marisa Gonzaga e SOUZA, Marlúcia Santos "Os professores e a construção do eco-museu no município de Duque de Caxias (RJ): um relato de experiência. “ IN PEREZ, Carmen Lucia Vidal,

TAVARES, Maria Tereza Goudard, ARAUJO, Mairce da Silva. (Org.) Memória e patrimônios; experiências em formação de professores. Rio de Janeiro: EdUERJ, 2009.

SILVA, José Antônio Seixas da. Fazenda São Bento: apogeu e declínio no Vale do Rio Iguaçu. In. Revista Pilares da História, Ano X, Edição Especial, agosto de 2011. p.38-47.

SILVA, Renato Mendonça Barreto da. Nos passos biográficos: um olhar sobre os palhaços da Folia de Reis Flor do Oriente. In Revista Pilares da História. AnoX, Edição Especial, agosto de 2011.p.8-21

SIQUEIRA, Gisele dos Santos. Getúlio Cabral: trajetória de morte de um militante comunista na Baixada Fluminense e em Salvador. Primeiros escritos. In. Revista Pilares da História, Ano X, Edição Especial, agosto de 2011, p.69-78. 
SOUZA, Eldemar de. Solano Trindade e eu. In. Revista Pilares da História. Ano VII, n.8, maio de 2008.p. 25.

SOUZA, Marlucia Santos de. Memórias da emancipação e intervenção no município de Duque de Caxias nos anos 40 e 50. In Revista Pilares da História. Ano II n.3 Dez 2003. p.37-54.

. Escavando o Passado da Cidade - História Política da Cidade de Duque de Caxias. Duque de Caxias: APPH-Clio, 2014.

TORRES, Gêneses (org.) Baixada Fluminense: a construção de uma história -Sociedade, Economia, Política. Rio de Janeiro: Editora IPAHB,2004

TORRES, Rogério Em busca da memória: crônica, registros e poesias. Rio de Janeiro: 2003

TORRES, Rogério. Uma passagem pela Caxias dos anos 60., Mesquita: Edição do Autor, Gráfica Shaovan Ltda, 2001.

THOMPSON, E. A Formação da Classe Operária Inglesa. São Paulo: Paz e Terra, 1987.

Amália Cristina Dias da Rocha Bezerra: professora Adjunta do Departamento de Ciências e Fundamentos da Educação da Faculdade de Educação da Baixada Fluminense (FEBF-UERJ) e membro permanente do Programa de Pós Graduação em Educação, cultura e comunicação em Periferias Urbanas. Membro do Grupo de Estudos Históricos da Baixada Fluminense (GEHBAF).Doutora em História da Educação na Universidade Federal Fluminense (2012). Mestre em História da Educação pela Universidade Federal Fluminense (2008), onde obteve o prêmio Bolsa Nota 10 Faperj. Atuou como Professora Substituta de História da Educação na Universidade do Estado do Rio de Janeiro (UERJ) e na Universidade Federal do Estado do Rio de Janeiro (UFRJ). Bacharel e licenciada em História pela Universidade Federal do Rio de Janeiro (2005), período em que realizou estágios no Arquivo Nacional, no Ministério das Relações Exteriores e obteve bolsa de Iniciação Científica da Faperj. Lecionou na rede estadual de educação. Inserida na área de ensino e pesquisa em História da Educação, atuando principalmente nos temas: história regional da Baixada Fluminense; história dos processos de escolarização na Baixada Fluminense, história da profissão docente no Brasil; história da educação, história política e história do Brasil. 
Eliana Santos da Silva: mestranda do Programa de Pós Graduação em Educação, Cultura e Comunicações nas Periferias (FEBF/UERJ).

Artigo recebido para publicação em: Outubro de 2016.

Artigo aprovado para publicação em: Dezembro de 2016. 